\title{
TURKEY IN SOUTH-SOUTH COOPERATION: NEW FOREIGN POLICY APPROACH IN AFRICA ${ }^{1}$
}

\author{
M. Ozkan \\ Turkish National Police Academy, Ankara, Turkey
}

\begin{abstract}
It is a fair treatment, without any exaggeration, to argue that the rise of Turkey in Africa in multiple areas as an actor is rather novel for foreign policy of Ankara. From development assistance to economy, politics to security, Turkey is now an influential player in African politics. Turkey's Africa policy has more meaning than a normal foreign policy relation. It is also a mature deepening of SouthSouth cooperation (SSC) in Turkish foreign policy. One of the most novel parts of Turkey's foreign policy since 2002 is its endeavor to be part of the South - South cooperation and increase its visibilities in development aid projects. This involvement — both at state and NGO levels - is particularly palpable on the African continent. Rather than following the footsteps of other countries, such as traditional donors, Ankara has been trying to develop its own understanding and implementation — the Turkish way — based on experiences mostly gained from Balkans and Central Asian republics.

These dimensions explain Turkey's development policy at ideational, societal and institutional levels in Somalia and beyond in Africa. Religion along with trade is one of the key drivers of this policy at societal and state levels. At ideational front, there has been a new geographical imagination in Turkey that sees Africa from a totally different perspective comparing to a decade ago.
\end{abstract}

Key words: Turkey, SSC, Africa, Turkey-Africa Relations, Somalia

\section{DETERMINANTS OF TURKEY'S AFRICAN POLICY}

In 1990's, Turkey has been trying to figure out its role in global politics in the postCold War period. Many domestic political crises did not permit Ankara to develop a comprehensive foreign policy approach to the world. However, the main goal of becoming member of the European Union was not reached; the EU literally gave a cold shoulder and that provoqued a shock in Turkey. In that sense, Turkey's current Africa policy was mostly a response to the European Union's rejection of Turkey as a candidate member in 1997. As a result of this rejection, Turkey's political elites started to examine different options in expanding its foreign policy. The main focus of this re-orientation effort was on traditionally neglected areas, such as Africa, Latin America and Asia. These modest opening plans could not be launched, however, until four years later due to political and economic turbulence in the country [Ozkan, Akgun 2010]. Coherent and consistent policy implementation was finally possible when Turkey's Justice and Development Party (AK Parti) replaced a three-party coalition in 2002 [Ozkan 2011].

1 This article is partly drawn from the following articles: Mehmet Ozkan, A Turkish way of Doing Development Aid? An Analysis from the Somali Laboratory. In: South-South Cooperation Beyond the Myths. Ed. by Arlene B. Tickner and Isaline Bergamaschi. New York: Palgrave, 2017, p. 59-78; Mehmet Ozkan Turkey's Political-Economic Engagement in Africa. In: Emerging Powers in Africa: A New Wave in the Relationship? Ed. by Justin van der Merwe, Ian Taylor and Alexandra Arkhangelskaya. New York: Palgrave, 2016, p. 217-231. 
Since AK Parti came to power in 2002, there has been a huge transformation in Turkish foreign policy. Until early 2000's, Turkey had largely followed a onedimensional foreign policy based on Western orientation despite different push factors coming from society to reach out to different parts of the world such as the Middle East, Africa, Asia and the Balkans. In those years, the state elite mostly acted upon the need to satisfy the social pressure whenever a crisis emerged, such as during the Bosnia war, but these shifts were neither deep-rooted nor comprehensive, rather based on ad hoc policies. Since 2002, one can talk about a 'period of openings' to previously neglected regions of the world in Turkish foreign policy to widen Turkey's options in international politics. However, these openings have occurred not only in economic and political terms, but also have strong social and religious dimensions.

Second, economic openings are central to Turkey's efforts to reposition itself in a changing global economy. The struggle to redefine a worldview, which concentrated on economics, has led the way and laid the foundations for the definitions of a new "national role" and foreign policy orientation, which have manifested themselves even more during the AK Parti era. Under Erdogan's leadership, Turkey has been trying to develop a new regional and global perspective based especially on historical and cultural components. Ankara's proactive and dynamic openings towards different regions of the world have been systematic and important initiatives rather than being appendages to its relations with the West [Davutoglu 2008].

Third, the political foundations of Turkey's openings, which are parallel to the two aforementioned approaches, are to increase Ankara's activities in all regions, international organizations and international relations, and to increase Turkey's activities to contribute to regional and global peace [Donelli, Levaggi 2016]. In that sense, Turkey wants to display an active presence in all international and regional organizations and has determined its foreign policy inclinations within this framework ${ }^{2}$. Turkey's observer status in the African Union, its partnership of dialogue in the Association of Southeast Asian Nations (ASEAN), its active stance in the G20 and its non-permanent member status in the UN Security Council during 2008 - 2010 have to be evaluated within this framework.

Ankara's African policy is only meaningful if one considers the overall foreign policy change in Turkey. Within this transformation, the details of Ankara's African policy can be examined in five phases; each of them indicates a different level of understanding of, and approach to, the continent. The period between the AK Parti's rise to power in 2002 and the designation of 2005 as the "Year of Africa", represented a preliminary stage in Turkey's foreign policy towards Africa. It was during these years that initial assessments of Africa's potential were made and Turkish officials held lowerlevel meetings with their African counterparts. The designation of 2005 as the "Year of Africa" represented an unmistakable sign of Turkey's commitment to building stronger relations with Africa [Siradag 2013].

2 Ahmet Davutoglu. 'Principles of Turkish Foreign Policy" Address by H.E. Foreign Minister of Republic of Turkey at the SETA Foundation's Washington D.C. Branch, 8 December, 2009. URL: http://www.setadc.org/images/stories/food/FM\%20of\%20Turkey\%20A.Davutoglu\%20Address\%20 at\%20SETA-DC\%2012-08-2009.pdf (accessed 25.12.2009). 
The second period, which started in 2005 and ended with the First Turkey-Africa Summit in 2008, marked a period of diversification of relations across a range of areas, including politics and the economy. During this period, Turkey-Africa relations made more progress than the Turkish authorities had initially predicted, while both sides became more familiar with their counterparts.

The third period began with the 2008 summit and continued until then-Prime Minister Recep Tayyip Erdogan's August 2011 visit to the Somalian capital Moghadishu. This was when Turkey-Africa relations assumed a multi-dimensional nature. While the Turkish government launched embassies in various African countries, the nation's trade volume with Africa quadrupled from 4 billion USD to approximately 18 billion USD. Following phase one's formative nature, phases two and three involved heightened complexity of Turkey's African policy.

It was during the fourth period, which began with Erdogan's official visit to Somalia that Turkey-Africa relations evolved into a more mature political relationship [Ozkan, Orakci 2015; Ozkan 2016]. In 2011, the Turkish government's Somalia initiative entailed the nation's focus on high politics, i.e., political matters and security issues, in addition to mere economic ties and humanitarian or development aid. The restoration of relative public order and the world's renewed interest in the Somalia conflict elevated Turkey to being a prominent stakeholder whose opinions were widely appreciated. As a result of this, the Turkish authorities met with representatives from the EU, Great Britain, Spain, Norway and the United States, among others, on African issues [Davutoglu 2012]. In this period, Turkey has consolidated its position as an important actor in Africa.

The end of 2014 marked the beginning of the fifth period in Turkey-Africa relations. This period arguably has focused on the "normalization" and institutionalization of relations. Therefore, this period has particular importance, as it holds the key to consolidating existing achievements and developing a more systematic approach. At that point, there were two pressing issues at hand. First, the second Turkey-Africa Partnership Summit was held in Malabo, Equatorial Guinea in November 2014. The Malabo summit paved the way for the full normalization of the Turkish government's relations with African countries. Previously, most of the African leaders attending the first Turkey-Africa Summit in 2008 were reported to have had serious doubts about the sincerity of Turkey's interest in the continent and had raised questions about the nation's agenda. However, the Malabo Summit focused on the possibility of expanded cooperation and maximizing mutual benefits in future thereby assuaging the African leaders' concerns ${ }^{3}$.

A second imperative for the current phase is to deepen and broaden relationships. Thus far, government agencies including the Turkish Cooperation and Coordination Agency (TIKA), the Presidency for Turks Abroad and Related Communities (YTB), and the Presidency of Religious Affairs (Diyanet), even Turkish Airlines as company [Anaz, Akman 2017], have sought to independently explore the African continent and to develop their own perspectives. This has resulted in further diversification of Turkey's interactions on the continent [Kavas 2006].

\footnotetext{
3 Ibrahim Kalin. A new phase in Turkish-African relations. Daily Sabah, 22 November, 2014.
} 
Overall, Turkey's mode of engagement with Africa has been a slowly deepening process with new elements being added as time passes. Similarly, new actors and institutions from the Turkish bureaucracy have also been involved in shaping Africa policy; while African partners' interests in developing these relations have also gradually increased [Donelli 2018]. One can now view the relationship between Turkey and Africa as fully-developed with all relevant actors contributing. This process has thus led to normalization of these relations at social, political and economic levels. Turkey has transitioned from being a "new" entrant into the African space to being an increasingly established partner with Africa [Langan 2017].

\section{SOUTH-SOUTH COOPERATION IN TURKISH FOREIGN POLICY: TOWARDS EXTENSION AND INSTITUTIONALIZATION}

In this section, it is argued that Turkey's official aid is very much connected to Ankara's geographical and social interest as well as trade considerations with African recipient countries. Since its involvement in Somalia in 2011, Turkey is eager to become a humanitarian actor on the continent rather than merely an economic power or donor. Turkish aid is a process of geographical extension and institutionalization.

Turkey started its aid activities as early as 1985 . These became more coordinated once TIKA was founded in 1992. TIKA has coordination offices in fifty countries in Africa, Asia, Latin America, Balkans and Europe for delivering development assistance through technical projects and humanitarian activities. TIKA is an autonomous organization under the tutelage of the Prime Ministry. Its main function is to establish a bridge between development partners' needs and relevant Turkish ministries and agencies. TIKA is also the main responsible state institution on official development assistance (ODA) reporting and data collection. TIKA partners with a number of international organizations, including the UN, OECD, UNESCO and the EU institutions. TIKA typically provides technical cooperation projects, direct investments, loans and credits, humanitarian assistance, peace building assistance and contributions to international organizations.

TIKA was initially established to help the transition of in Central Asia, the Caucasus and the Balkans. However, as of 2003 it was transformed into a more global aid agency and has expanded its area of operations. For example, in 1992-2002 TIKA conducted 2,346 projects and activities in total, and its annual average number of projects and activities was only 256 . However, TIKA's total projects and activities expanded to 2,780 in 2003-2006, notably in Africa, the Middle East and North Africa. TIKA-sponsored projects towards the Middle East and Africa rose from 45 in 2005 to 150 in 2006. The first TIKA Program Coordinator Office in Africa was opened in Addis Ababa in 2005, followed by others in several other countries. TIKA offices support development projects in their respective regions, and from these three offices it operates in thirtyseven countries in Africa. With the opening of new embassies all over the continent (29 new opened, now total 41), the number of TIKA offices in Africa is likely to increase as well, thus increasing Turkish aid flow to the continent.

The amount of TIKA's international assistance has increased substantially since 2004. The annual amount between 2002 and 2004 was around 80 million USD, while the annual average reached 700 million USD between 2006 and 2009. In 2013, Turkey's 
ODA reached 3.308 billion USD. Multilateral ODA accounted for 5\% of Turkey's total ODA in 2013, provided through the UN (accounting for $21 \%$ of its multilateral ODA) as well as through the World Bank Group and regional development banks. Although Africa still represents a quarter of TIKA budget, Turkish ODA to Africa increased by $67 \%$ from 30.9 million USD in 2009 to 400 million USD in 2014. Aid to the LDCs has also increased to 158.95 million USD in 2010. The bulk of bilateral assistance was delivered as project and program aid, technical assistance and involvement in postconflict, peace building operations and humanitarian aid [Ozkan 2017: 61].

Besides TIKA, Turkey counts with other aid channels. The second institution that provides international aid is the Ministry of Education and third is the military. The Ministry of Education usually provides scholarships to students and supports educational institutions abroad. The military is mostly involved in training. The Religious Directorate for Religious Affairs (Diyanet) and the Turkish Red Crescent (Kizilay) can also be mentioned here. Through Eximbank ${ }^{4}$ and the Ministry of Economy, Turkey also gives direct economic support to Africa's development but their involvements, as state institutions are usually minor.

Since 2002, a new Turkish foreign policy was established, which includes active participation in the fight against poverty and increasing development and humanitarian aid. The speed of change is impressive: in less than a decade, Turkey has shifted from having almost not-more-than-formal relations with Somalia to establish an increasingly comprehensive partnership. SSC was not present until the early 2000's in Turkish discourse and practice. According to the Foreign Ministry website, net disbursements of South-South cooperation budget for Turkey (bilateral and multilateral) were 602 million USD in 2007; while in the same year it was 343 million USD for Colombia, and 270 million USD for the Republic of Korea. Between 2002 and 2007, as the financial amount for the SSC was multiplied by 3 times in Colombia, 4 times in the Republic of Korea, in Turkish case, the SSC fund increased for 20 times.

TIKA and Turkish civil society organizations have been active for a long time in the Middle East, Central Asia and the Balkans. However, the country has experienced an increased interest and a rise in the amount of both official and unofficial aid to Africa in the last decade. Whereas Turkey recorded approximately seven percent annual economic growth rate until 2011, her ambition and scope of activities in the field of development aid have increased in tandem. In parallel with its economic dynamism ${ }^{5}$, Turkey has been continuously increasing its official development aid since 2004 and implementing opening policies toward historically neglected areas in Turkish foreign policy. The basic reason for this geographical extension of influence to the African continent lies in the re-orientation of Turkish foreign policy which basically has, at least, three dimensions: (i) a new geographical perception in Ankara's outlook towards the whole world, which accepts that Africa and Asia are not regarded as distant and troubled

4 Turkish Eximbank is official export credit agency and has been mandated to support foreign trade and Turkish contractors/investors operating overseas. See: Eximbank. URL: www.eximbank.gov.tr (accessed 25.12.2009).

5 Turkey's nominal GDP in 2014 reached US\$806 billion. According to GDP figures, Turkey is the 17th biggest economy in the world and the 6th in Europe. See EU Bilateral Trade and Trade with the World 2013. 
regions but as possible partners; (ii) considerable efforts to re-position Turkey as a "central country" rather than a "bridge" between the East and West and developing an institutionalized partnership with Asia and Africa in a changing global economy in order to play a more active role in international relations and (iii) an increase in activities in all regions and international organizations in order to contribute to regional and global peace [Ozkan 2011: 116-117]. Ankara's increasing interest in Somalia is part and parcel of this policy. Turkey's contribution as a donor was not visible until recently because it was both modest and poorly coordinated, but is increasingly palpable, especially in Somalia.

\section{TURKEY AS A SSC ACTOR IN AFRICA}

Turkey's interest in South-South cooperation and its implications for foreign policy can be analyzed from various aspects. This issue has become an increasing topic in Ankara's approach to different parts of the world, however, for many Turkish foreign policy observers this is still an under-studied and under-theorized issue. This section aims to provide some inputs for a better understanding of this newly emerging element in Turkish foreign policy.

\section{Aid and Humanitarianism: Entering the Field}

Although Turkey's relationship with Africa has evolved and become increasingly complex, Turkish authorities remain aware of the importance of humanitarian assistance in Ankara's relations with the African continent [Hasimi 2014]. Turkey sees the humanitarian dimension as an entry point to the continent [Uchehara 2008]. In line with this policy, Turkish Cooperation and Coordination Agency has established representation offices in 21 countries in Africa to provide grants to the most disadvantaged nations. In the last decade, aid has been one of the strongest foreign policy elements in Turkey's overall foreign policy in general, and its Africa policy in particular. It has been arguably part of the country's soft power strategy ${ }^{6}$ in African countries [Anaz 2014].

TIKA currently has operations in over 40 countries in Africa as part of Ankara's developmental aid policy. TIKA was initially established to help in the transition of the states in Central Asia, Caucasus, and the Balkans. However, after the year 2003, the organization has been transformed into a more global aid agency and has expanded their area of operations, including in Africa. Through its offices, Turkey has shown a strong will to widen the cooperation with Africa, particularly with regard to projects that provide technical assistance to Africa. Turkey's former President Abdullah Gul explained that Turkey attempted to build relations with Africa by making "health, education, agriculture, environment, infrastructure and capacity-building" strategic areas . These areas continue to basically constitute the essence of Turkey's humanitarian aid to Africa.

\footnotetext{
${ }^{6}$ Lough Richard. Turkey Tries Out Soft Power in Somalia. Reuters, 3 June, 2012. URL: http://www.reuters.com/article/somalia-turkey-idUSL5E8GP2LP20120603 (accessed 28.01.2016).

7 Gul A. Africa's development needs: state of implementation of various commitments, challenges and the way forward. Remarks by President of Turkey in New York, 22 September 2008. URL: http://www.un.org/ga/president/62/ThematicDebates/adn/turkey.pdf (accessed 15.03.2016).
} 
Besides the activities of TIKA, Turkey has also utilized international organizations to provide aid to Africa. For example, through the World Health Organization, World Food Program (WFP), and the Red Crescent, Turkey has donated 7.5 million USD to various African countries to assist them to cope with the negative effects of drought and other natural disasters. The amounts, however, are very small. In 2008, Turkey allocated 3.5 million USD as humanitarian aid through the WFP, while in 2009, made a modest donation of half a million dollars to the African Union budget ${ }^{8}$. In a similar vein, in 2007, Turkey, for the first time hosted a summit of the Least Developed Countries (LDC), in Istanbul, 33 of which are in Africa (out of 49 members). During this summit, Turkey committed 20 million USD development aid for their use. To show Turkey's commitment to development of the LDC members, Ankara also hosted the fourth conference on Least Developed Countries in the first half of 2011.

\section{Trade and Institutional Cooperation: Making Relations Meaningful}

Nothing can summarize the change in Turkey-Africa relations better than the increasing trade and institutional cooperation between the two partners. As mentioned above, the year 2005 was a turning point in Turkey's relations with Africa. Turkey obtained observer status in the African Union (AU) in 2005 (which later declared it a strategic partner in January 2008). In May 2008, Turkey joined the African Development Bank and strengthened its relations with the Intergovernmental Authority on Development in East Africa and the Economic Community of West African States [Ozkan 2010]. The Foreign Economic Relations Board of Turkey (DEIK) established eight Business Councils as part of Ankara's attempts to increase business activities with Africa.

In general, Turkey's approach to developing trade with African nations seems to differ from that of a number of nations seeking business opportunities on the continent, whose overriding interests are Africa's oil resources. As a mid-sized nation with a developing economy, Turkey carries none of the free market capitalist baggage aimed at securing the best deal at any cost that Africans so resent. By concentrating on lower profile development issues such as agriculture, arguably Turkish initiatives carry the promise of affecting genuine change in the lives of masses of Africans.

Both in the literature and society, there is a general assumption that what lie behind the new interest of emerging states in Africa is energy resources. This cannot be rejected at outright as it is documented well in other places [Kornegay, Landsberg 2009]. In the case of Turkey, this has been rejected by many Turkish officials arguing that Turkey's interest is based on exchanging competencies and technologies with Africa.

While these developments at political and institutional level are important, Turkey's relationship with Africa is underwritten by rising bilateral trade. Turkey's trade volume

8 African Union Commission. The Government of the Republic of Turkey made a donation to the African Union Budget. African Press Organisation. 2009. from https://appablog.wordpress.com/2009/ 03/03/the-government-of-the-republic-of-turkey-made-a-donation-to-the-africanunion-budget/ (accessed 08.06.2016). 
with African countries was only 5.4 billion USD in 2003; it increased more than twofold to exceed 16 billion USD in 2008 and despite the economic crisis it did not lose its pace, reaching around 23 billion USD in $2015^{\circ}$. Yet, considering Turkey's total trade volume with the world as a whole, current trade volumes with African countries are not significant. Nonetheless, Turkey's target is to increase trade volumes with Africa to around 50 billion USD by 2023.

\section{Constructive State-building: Somalia Experience}

In August 2011, shortly after famine was officially declared in parts of southern and central Somalia, then-Prime Minister Recep Tayyip Erdogan led a delegation composed of four ministers and members of Turkey's cultural and business elite to visit Mogadishu. Prime Minister Erdogan also brought his family, to highlight the need for greater famine relief, and to bring moral support to Somalis. This was the first visit to Mogadishu by a head of state or government from outside Africa in almost 20 years [Ali 2011] and marked the start of a sustained increase in Turkish engagement in Somalia. In January 2015, Erdogan — now as president of Turkey - returned to Mogadishu for talks with the government and to inaugurate several projects, including a hospital built with Turkish support. Both visits were widely celebrated, and Erdogan personally appears to be quite popular, especially in Mogadishu, where most of Turkey's aid projects are concentrated.

However, Turkey's engagement has not been without its opponents. In July 2013, the Turkish embassy in Mogadishu was attacked, leaving one dead and three Turkish security force members wounded. Shortly before President Erdogan's January 2105 visit, militants attacked the hotel where the Turkish forward planning team was based. Harakat al-Shabaab al-Mujahidin ('al-Shabaab') claimed responsibility for both attacks.

Ankara's involvement in Somalia can be explained with a special focus on three approaches. Humanitarianism has been the main theme and since the beginning this has been one of the most pronounced official discourses on Somalia. Humanitarianism does not only have the components of emergency aid, but also included a development aid aspect. With a mixture of both aid policies, Turkey has become a prominent figure in Somalia ${ }^{10}$.

The second aspect of Turkey's Somalia policy is related to implementation of its development policies. There has been a convergence of state apparatus and civil society organizations on the ground [Wasuge 2016]. Albeit lacking in coordination, this unofficial coalition has boosted Turkey's overall visibility in Somalia. Most importantly, Turkish developmental activities in Somalia, irrespective of whether carried out buy state institutions or civil society have been attributed to Turkey, making it appear as if Ankara is the initiator.

9 Turkey-Africa relations. MFA — Turkish Ministry of Foreign Affairs. 10 May, 2016. URL: http://www.mfa.gov.tr/turkey-africa-relations.en.mfa (accessed 17.01.2017).

${ }_{10}$ Mensur Akgün. Somali'de Yeni Bir Devlet İnşaa Ediyoruz. Star, 22 December, 2012. URL: http://haber.stargazete.com/yazar/somalide-yeni-bir-devlet-insa-ediyoruz/yazi-714006 (accessed 20.02.2014). 
The third aspect of Ankara's involvement is to be found in its regional approach. Turkey has realized that the "Somalia issue" goes beyond the nation-state, and includes regional and global dimensions. This policy has mostly stemmed from a geopolitical understanding that without solving the regional balance, any peace in Somalia is likely to be temporary. In the Fifth Annual Meeting of Ambassadors in Ankara, in January 2013, then-Turkish Foreign Minister Ahmet Davutoglu demonstrated Turkey's recognition of the issue at hand, when he announced Turkey's integrated strategy addressing the issues in eastern Africa as a whole.

Turkey has delivered more than 500 million USD in aid to Somalia through its developmental and humanitarian projects. Turkey's developmental and humanitarian projects have centered on a number of projects. These interventions have focused on six aspects: transport (air and road linkages); infrastructure (roads, airport, renovations, water and sanitation); healthcare (building hospitals and supplying and training healthcare workers); education (provision of scholarships and building of schools); religious (training of Imams and restoration of mosques); and traditional humanitarian activities (refugee camps and orphanages).

Many Turkish NGOs have also been active in the country, especially in central and southern Somalia. Turkish NGOs have circumvented restrictions on foreign organizations by working with local Somalia NGOs to deliver aid and implement their projects in distressed areas, or, in some cases, coordinated their projects from their headquarters in Turkey.

\section{RISING SECURITY PROVIDER IN AFRICA}

In the last several years, a new but significant component of Turkey-Africa relations is underway: security. Turkey has always been hesitant to export security through its foreign policy, but this is changing now. Since long time, Turkey has had military presence in some UN missions, such as in Lebanon; and this was part of Ankara's commitment to global peace. However, within the new foreign policy of Turkey, sending military to international missions is not considered as 'sufficient' in terms of Ankara's geopolitical interest. In 2017, Turkey opened two military bases. One is based in Qatar and the other one is in Somalia.

As part of this policy change at home, since 2011, Turkey has tried to contribute to increasing security in Africa. Security elements of Turkey-Africa relations have basically three dimensions. First, Turkey has contributed to international efforts to ensure peace and stability in Africa. Ankara contributes to the United Nations missions deployed in the continent. As of August 2015, Turkey took part in seven of the nine existing UN missions in Africa with its police and military officers. In addition, by the end of 2014, military training was provided in Turkey for 2.200 military personnel from over 20 African countries. For the period of 2015-2016 Turkey is expected to receive more than 1.200 African military personnel for training ${ }^{11}$.

11 Feridun Sinirlioglu. Turkey In Africa; A Humanitarian Approach. The New Times, 17 November, 2015. URL: http:/www.newtimes.co.rw/section/article/2015-11-17/194445/ (accessed 16.04.2016). 
Second, Turkey has contributed to security of international trade, particularly maritime security, via its efforts in the Horn of Africa. Since 2009, Turkey has taken an active role in combatting piracy in the Gulf of Aden and has provided military support to fight against piracy in cooperation with the EU and the UN. Thus far, four frigates have been deployed consecutively to combat piracy.

Third, security also underpins Ankara's state-building efforts in Somalia. Turkey, for instance, provides support to the Somali central government in the area of training security services. Turkey dedicated a budget of 20 million Turkish Lira for the restructuring of the Somali army and its police forces since $2011^{12}$. One of its projects is to build a non-commissioned officer school with a capacity of 100 student-officers in the first phase, followed by plans to start building the foundations of professional military ground, air, and naval schools. Turkey's General Directorate of Security, the Turkish General Staff, and the Ministry of Foreign Affairs have conducted various studies on how to best restructure the Somali army and police forces. Building infrastructure, configuring, and training the Somali police are all part of Turkey's development assistance. To this end, it has brought 60 Somali police officers to Turkey for training, through the General Directorate of Security. The General Directorate of Security has also prepared the design of their police uniforms. Subsequently, a police team of more than 500 police officers has come gradually to Turkey for training over the last three years ${ }^{13}$.

Al-Shabaab (an extremist group that controls much of Southern Somalia) launches periodic attacks against Turkish targets. Its goal is to try and deter Turkey from continuing its aid activities in the country. For instance, in an attack targeting the Red Crescent aid convoy on April 15, 2013 fifteen Somali aid workers were killed and four Turks were wounded. Also, a Turkish businessman was assassinated at the hotel he was staying in Mogadishu on May 25, 2012. Al-Shabaab claimed responsibility for two more recent deadly attacks. One of these attacks was a suicide attacks aimed at public buildings in Mogadishu in October 2011 that led to the deaths of 70 students to whom Turkey had provided scholarships. This attack was perceived as an attack against Turkey. Turkey sent an air ambulance to treat the surviving the injured students. Another major attack was a direct attack on a Turkish target. It was carried out by a suicide bomber located in front of an annex building of the Turkish Embassy, on July 27, 2013 in Mogadishu. One of four Turkish special operations police was killed in the clash while others were injured. On tweeter, Al-Shabaab's accusing Turkey of supporting a non-Islamic and secular structure in Somalia.

Turkey has set up its biggest overseas military base in the Somali capital, Mogadishu, increasing Ankara's presence in the Horn of Africa country in October 2017. The military base aims to train 10.000 Somali troops and has the capacity to train at least 1.500 soldiers at a time. The military base is likely to boost Turkey's soft power in the region and enhance its status as an essential player in regional security.

12 TSK Somali Askerini Eğitecek. TimeTurk, 4 March 2013. URL: http://www.timeturk.com/tr/ 2013/03/04/tsk-somali-askerini-egitecek.html\#.U0KBvqh_uBI (accessed 10.06.2013).

13 Ibid. 
However, Turkey's intention goes beyond this. In a visit to Sudan in December 2017 , President Recep Tayyip Erdogan officially asked his Sudanese counterpart for renovation of the Suakin Island, which Ottomans used the port city to secure Hejaz province present-day western Saudi Arabia — from attacks on the Red Sea front.

The island has both strategic and historical importance for Turkey. Historically, until the 19th century, Suakin was the residential address of the Ottoman Empire's Habesh Eyalet, which is today's Eritrea, Djibouti and northern Somalia. Strategically, it is a port city located northeast of Sudan; Suakin was the most significant port in Nubia. After the establishment of Port Sudan, Suakin diminished in importance. Ankara's interest is not only reviving the island and sends a strong deepening message to TurkeySudan relations; but also to open another military in future. If that happens, Ankara's role as a military actor will not only be strengthened, but also will add a different dimension to Turkey-Africa relations.

\section{CHALLENGES AND FUTURE OF THE RELATIONS}

As explained previously, Turkey started its relations with Africa with a heavy focus on aid and humanitarian dimensions; but it went beyond this and accelerated increasing trade and deepened its state-building and security component. However, despite the presence of this positive trajectory, Turkey-Africa relations are not without risks.

One can argue that there are two fundamental risks with the future direction of Turkey's relations with the African continent. The first issue relates to the emerging Africa fatigue in the country, which has developed due to a lack of sophisticated vision. The vision of the opening period since 2002 has elapsed and now an expanded vision and accompanying plan is needed. This problem, which presents itself inside certain government agencies today, could possibly reduce the African initiative from an effort to reposition Turkey in the global economic and political system, into a mere diversion in foreign policy.

At present, Turkey_Africa relations appear to be stable. The Turkish government's efforts tend to be appreciated across the continent. It is possible, nonetheless, to identify certain shortcomings. The most important point right now relates to the challenging task of making the country's efforts matter on a regional and global scale.

Up until 2011, key African countries believed Turkey's sudden interest in Africa's affairs to be primarily economically motivated — that is why they concentrated on short-term benefits at the expense of the Turkish government's long-term contributions. Ankara's policy toward Somalia, however, helped transform African leader's perceptions of Turkey at national and regional levels ${ }^{14}$. Furthermore, official visits by Turkish leaders made positive contributions to Turkey's image in the continent. The upcoming years, though, will put Turkey's position as a security actor alongside other critical players such as France, the United Kingdom, and the United States to the test. In terms of the emerging powers' role in Africa, one can argue that Turkey's place is now firmly secured as an emerging power in the continent especially with regard to trade and humanitarian aid.

\footnotetext{
${ }^{14}$ Harper M. The Unlikely Love Affair Between Two Countries. BBCNews, 15 December, 2014.
} 
Domestically, the biggest challenge is the lack of understanding and interest regarding Africa both in policy-circles and academia within Turkey. This continues to be present, despite more than a decade of engagement with the continent. There still remains an acute shortage of trained Turkish experts on African affairs. Although various Turkish institutions have launched Africa research centers in previous years, these organizations remain both ill-equipped and prone to reproducing extremely Orientalist approaches that are on the verge of becoming obsolete in the West. The fact that Turkish institutions falsely present Western arguments as new and original findings undermines the country's position in Africa in terms of academic expertise. In this sense, the Turkish government is required to take necessary steps to encourage graduate students and doctoral candidates to specialize in African studies in an effort to follow continental developments more closely. Furthermore, Turkish universities may establish Africa research centers to host lectures by prominent Africanist academics in order to familiarize the continent's leading minds with Turkey.

\section{CONCLUDING REMARKS}

In general, Turkey's opening to Africa is a result of both Turkey's domestic transformation and change in the global political economy. This opening has given a new impetus for SSC as foreign policy tool for Ankara. Turkey's domestic transformation has challenged the traditional Turkish partners in the economy and aimed at diversifying its trade alternatives in line with change in the global political-economy power configuration. Change in the international system led countries to define their own interest in a newly emerging system [Anaz, Ozcan 2016]. Turkey's response to such changes has been to define a multidimensional foreign policy and developing economic and political relations with not only immediate neighbors but also other regions and continents. Turkey's Africa opening is part and parcel of this new redefinition of Turkish foreign policy.

Turkey's Africa opening and SSC policy have, so far, been one of the most successful foreign policy strategies in terms of economic, political and social gains. Relations between African countries and Ankara have turned to be mutually beneficial for both parts and this has created a momentum and willingness to deepen these ties. Turkey's president Erdogan has visited 28 different African countries since 2004, of which Erdogan has paid official visit to some countries more than once. Today, Africa is considered as a natural ally in perception of Turkish people and the issues of Africa is so normalized that nobody - even opposition parties - criticizes these relations at all. Some African issues, like that of Somalia, are literally internalized and now are considered as part of Turkey's domestic agenda.

Turkey-Africa relations are likely to continue in coming years, because it has been bought at social level. Politically speaking, more engagement with Africa has created a better understanding of Africa and its potentials in Turkey and created a successful example of South-South Cooperation. In coming years, whether the global and domestic developments may bring any change both in nature and speed of TurkeyAfrica relations is yet to be seen. However, redefinition of Africa both at conceptual and political levels in Turkish foreign policy represents a novelty. 


\section{REFERENCES}

Ali, A. (2011). Turkey's Foray into Africa: A New Humanitarian Power? Insight Turkey, 13 (4), $65-73$.

Anaz, N. (2014). The Geography of Reception: Why Do Egyptians Watch Turkish Soap Operas? The Arab World Geographer, 17 (3), 255-274.

Anaz, N. \& Ozcan, C.C. (2016). Geography of Turkish Soap Operas: Tourism, Soft Power, and Alternative Narratives. In: Alternative Tourism in Turkey. Ed. by I. Egresi. Springer International Publishing, Cham, p. 247-258. DOI: 10.1007/978-3-319-47537-0.

Anaz, N. \& Akman, E. (2017). Turkey's Soft Power Capacity: Geopolitics of Aviation and the Turkish Airlines. The Arab World Geographer, 20 (4), 303-316.

Davutoglu, A. (2008). Turkey's New Foreign Policy Vision: An Assessment of 2007. Insight Turkey, $10(1), 77-96$.

Davutoglu, A. (2012). 2013 Yılına Girerken Dış Politikamız. Ankara: Dışişleri Bakanlığı. (in Turkish).

Donelli, F. (2018). The Ankara consensus: the significance of Turkey's engagement in sub-Saharan Africa. Global Change, Peace \& Security, 30 (1), 57-76. DOI: https://doi.org/10.1080/ 14781158.2018.1438384.

Donelli, F. \& Levaggi, A. G. (2016). Becoming Global Actor: The Turkish Agenda for the Global South. Rising Powers Quarterly, 1 (2), 93-115.

Hasimi, C. (2014). Turkey's Humanitarian Diplomacy and Development Cooperation. Insight Turkey, 16 (1), 127-145.

Kavas, A. (2006). Osmanli Afrika Iliskileri. Istanbul: Tasam.

Kornegay, F.A. \& Landsberg, C. (2009). Engaging emerging powers: Africa's search for a 'common position'. Politikon, 36 (1), 171-191. DOI: https://doi.org/10.1080/02589340903174717.

Langan, M. (2017). Virtuous power Turkey in sub-Saharan Africa: the 'Neo-Ottoman' challenge to the European Union. Third World Quarterly, 38 (6), 1399-1414. DOI: https://doi.org/10.1080/ 01436597.2016.1229569.

Ozkan, M. (2010). What Drives Turkey's involvement in Africa? Review of African Political Economy, 37 (126), 533-540. DOI: 10.1080/03056244.2010.530952.

Ozkan, M. (2011). Turkey's 'New' Engagements in Africa and Asia: Scope, Content and Implications. Perceptions: Journal of International Affairs, XVI (3), 115-137.

Ozkan, M. (2016). Turkey's Political-Economic Engagement in Africa. In: Emerging Powers in Africa: A New Wave in the Relationship? Ed. by J. van der Merwe, I. Taylor and A. Arkhangelskaya. New York: Palgrave, p. 217-231.

Ozkan, M.A. (2017). Turkish way of Doing Development Aid? An Analysis from the Somali Laboratory. In: South-South Cooperation Beyond the Myths. Ed. by A.B. Tickner, I. Bergamaschi. New York: Palgrave, p. 59-78.

Ozkan, M. \& Akgun, B. (2010). Turkey's Opening to Africa. The Journal of Modern African Studies, 48 (4), 525-546. DOI: https://doi.org/10.1017/S0022278X10000595.

Ozkan, M. \& Orakci, S. (2015). Turkey as a "political" actor in Africa — an assessment of Turkish involvement in Somalia. Journal of Eastern African Studies, 9 (2), 343-352. DOI: 10.1080/17531055.2015.1042629.

Siradag, A. (2013). The Making of the New Turkish Foreign and Security Policy towards Africa: The Rationale, Roots and Dynamics. Africa Insight, 43 (1), 15-31.

Uchehara, E.K. (2008). Continuity and Change in Turkish Foreign Policy Toward Africa. Gazi Akademik Bakış, 2 (3), 43-64.

Wasuge, M. (2016). Turkey's Assistance Model in Somalia: Achieving Much With Little. Mogadishu: The Heritage Institute for Policy Studies.

Received: 15.08 .2018 
For citations: Ozkan, M. (2018). Turkey in South - South Cooperation: New Foreign Policy Approach in Africa. Vestnik RUDN. International Relations, 18 (3), 565-578. DOI: 10.22363/2313-0660-201818-3-565-578.

About the Author: Ozkan Mehmet — PhD, Associate Professor, Turkish National Police Academy, Ankara, Turkey (e-mail: metkan82@hotmail.com).

DOI: 10.22363/2313-0660-2018-18-3-565-578

\title{
УЧАСТИЕ ТУРЦИИ В СОТРУДНИЧЕСТВЕ ЮГ-ЮГ: ВНЕШНЕПОЛИТИЧЕСКИЕ НОВАЦИИ НА АФРИКАНСКОМ НАПРАВЛЕНИИ
}

\author{
М. Озкан \\ Национальная полицейская академия Турции, Анкара, Турция
}

Рост влияния Турции в Африке во многих сферах является достаточно новым явлением для внешней политики Анкары. Динамика движения от помощи развитию к полноценному экномическому сотрудничеству, от политического измерения к обеспечению безопасности позволяет Турции претендовать на статус влиятельного актора в африканском регионе. Политика Турции в Африке что-то большее, чем просто внешнеполитические отношения. Это осознанное углубление направления сотрудничества по линии Юг-Юг.

Одним из новейших инструментов внешней политики Турции с 2002 г. является ее стремление стать частью сотрудничества Юг-Юг и повысить свою видимость в проектах помощи в целях развития. Это участие - как на уровне государства, так и на уровне НПО — особенно ощутимо на африканском континенте. Вместо того чтобы идти по стопам других стран-доноров, Анкара пытается развивать свое собственное понимание и реализацию - турецкий путь сотрудничества Юг-Юг, основываясь на опыте, накопленном в основном на Балканах и в республиках Центральной Азии.

В статье на концептуальном, социальном и институциональном уровнях анализируется политика Турции по содействию международному развитию в Сомали и в Африке в целом. Религия наряду с торговлей является одним из ключевых факторов этой политики на общественном и государственном уровнях. На идейном фронте в Турции появилось новое географическое видение, в рамках которого Африка рассматривается с совершенно иной точки зрения, чем десятилетие назад.

Ключевые слова: Турция, сотрудничество Юг-Юг, Африка, турецко-африканские отношения, Сомали

Дата поступления статьи: 15.08.2018

Для цитирования: Ozkan M. Turkey in South-South Cooperation: New Foreign Policy Approach in Africa // Вестник Российского университета дружбы народов. Серия: Международные отношения. 2018. Т. 18. № 3. C. 565-578. DOI: 10.22363/2313-0660-2018-18-3-565-578.

Сведения об авторе: Озкан Мехмет - доктор философии, доцент Национальной полицейской академии Турции, Анкара, Турция (e-mail: metkan82@hotmail.com).

(C) Ozkan Mehmet, 2018 